\title{
Kamilla Biskupska
}

Uniwersytet Opolski

\section{Pamiętam, że... 0 społecznej konstrukcji pamięci mieszkańców miast Ziem Zachodnich i Północnych na przykładzie Wrocławia}

(...) unia przeszłości z przyszłością zamieszkuje w samej idei miasta, tak jak pamięć cechuje życie każdego człowieka (Rossi, 1999, s. 130).

STRESZCZENIE Celem artykułu jest przedstawienie wątków pamięci społecznej, które z jednej strony opierają się na indywidualnym, potocznym doświadczeniu jednostki, z drugiej umieszczane są w społecznie wynegocjowanych ramach pamięci zbiorowej. Artykuł ten wpisuje się również w dyskusję nad miejscami pamięci i ich możliwą treścią - wykraczającą poza podtrzymujące pamięć zbiorową muzea, pomniki, upamiętniające tablice czy cmentarze - realizowaną w codziennym życiu jednostki. Przedmiotem analiz jest pamięć społeczna mieszkańców Wrocławia, ich konstrukcje światów społecznych opierające się na przestrzeni miasta obciążonej obcą kulturowo „pamięcią nieobecnych”.

\section{Wprowadzenie}

„Gigantyczny eksperyment społeczny” (Bartkowski, 2003, s. 195), jakim było przyłączenie do Polski Ziem Zachodnich i Północnych, stanowił przedmiot analiz socjologicznych (z różnym natężeniem) przez cały okres powojenny. Jednak nadal wiele zagadnień związanych z tym obszarem, szczególnie na poziomie mikrosocjologicznym, wymaga namysłu badawczego. Tematem tego opracowania jest zarysowanie możliwej problematyki

\section{SŁOWA KLUCZOWE}

PAMIĘĆ SPOŁECZNA, MIEJSCA PAMIĘCI, ANALIZA DYSKURSU, TOŻSAMOŚĆ, ZIEMIE ZACHODNIE I PÓŁNOCNE, WROCŁAW 
badań socjologicznych dotyczących pamięci społecznej kolejnych pokoleń mieszkańców Ziem Zachodnich i Północnych, budowanej w kontakcie z przestrzenią życia ${ }^{1}$ - „odziedziczonym", cywilizacyjnie obcym krajobrazem kulturowym². Przyjmuję tu perspektywę fenomenologiczną - przeszłość jest w tym ujęciu wpleciona w świat przeżywany jednostek (Lebenswelt - zob. Schütz, 1984): „Chodzi tu o świat, z jakim spotykamy się w codziennym życiu, dany w prostym i bezpośrednim doświadczeniu - szczególnie w spostrzeżeniu i jego derywatach: pamięci, oczekiwaniu itp. - niezależny od naukowej interpretacji i wobec niej pierwotny" (Gurwitsch, 1989, s. 151). Istotność wskazanego zagadnienia zauważył Jacek Leoński, pytając u progu XXI wieku:

Czy widok morza, gór, lasów, jezior czy miasta i wsi interesującej nas przestrzeni [Ziem Zachodnich i Północnych - K.B.] budzi jednakowe skojarzenia i jednakowe myślenie u mieszkańców reprezentujących różne pokolenia tych ziem? Czy widok ten jest „taki sam” dla repatriantów z Kresów Wschodnich, osadników z Polski centralnej, Wielkopolski i Śląska, czy Ukraińców przesiedlonych przymusowo z południowowschodniej Polski? (2014, s. 71).

Komunistyczna propaganda, kreująca obrazy piastowskości, a przez to swojskości Ziem Zachodnich i Północnych, zapewniała przybyszów o ich prawie do zasiedlenia owych „Ziem Odzyskanych":

Zabużański repatriant lub osadnik z centralnej Polski jechał na nowy obszar jako na teren wchodzący do jego ojczyzny. (...) W budowie tej nowej „małej ojczyzny” utwierdzała go wiara i pewność, że nie jest tu kolonizatorem na obcych terenach, lecz osiedla się na ziemiach, które wprawdzie należały do Niemiec, ale w wyniku wojny weszły znowu do Polski. Miał poczucie sprawiedliwości tych zmian (Nowakowski, 1967, s. 183).

Działania te skutecznie zamrażały możliwość „przepracowania” tych odmiennych kulturowo i ideologicznie wrogich (bo zarówno niemieckich, jak i burżuazyjnych) miast. Tę nadal niewidzialną w dyskursie publicznym (i być może prywatnym) dwuznaczność życia w powojennej rzeczywistości Ziem Zachodnich i Północnych przedstawił obrazowo urodzony we Wrocławiu w latach 50. XX wieku historyk literatury i eseista Stanisław Bereś:

(...) mieszkałem w niemieckim domu, w którym od całych pokoleń rodziły się niemieckie dzieci i umierali starcy. Spałem na niemieckiej kanapie, patrzyłem na niemieckie obrazy, kąpałem się w niemieckiej wannie, jadłem z niemieckich garnków i talerzy (...). Od dzieciństwa byliśmy wychowywani w nienawiści i strachu przed Niemcami, a jednocześnie cały ten nasz świat, cały ten kosmos życia codziennego, nawet gusta zostały uformowane w obrębie przedmiotów, sprzętów, form i ducha niemieckiego. Zdaje sobie Pan z tego sprawę? Myśli Pan, że to w żaden sposób nie wpływa na człowieka? (1993, s. 51).

\footnotetext{
Przestrzeń jako wymiar życia społecznego (inny niż miejsce) staje się coraz częściej przedmiotem zainteresowania badaczy społecznych - mowa jest nawet o zwrocie przestrzennym, który sprawił, że „przestrzeń przestała być traktowana przez badaczy wyłącznie jako element fizyczny, a zaczęto ją postrzegać jako wytwór życia społecznego, który zwrotnie na nie oddziałuje" (Rogowski, 2016, s. 125). W polskiej literaturze przedmiotu pionierskie w tym kontekście są prace Floriana Znanieckiego i Stefana Czarnowskiego, a współcześnie główne kierunki badań wyznaczają prace Aleksandra Wallisa i Bohdana Jałowieckiego (zob. Kaltenberg-Kwiatkowska, 2007).

${ }^{2}$ Krajobraz kulturowy rozumiem jako „zapis historii w konkretnej przestrzeni, na którego kształt oraz cechy tożsamości złożyły się czynniki zarówno pierwotne, pochodne od natury, jak i wtórne, będące czynnikiem działalności człowieka" (Kornecki, 1991, s. 19).
} 
Upływ lat i związane z tym wzrastanie kolejnych pokoleń polskich mieszkańców Ziem Zachodnich i Północnych przyjmowane były przez socjologów jako część naturalnego procesu asymilacyjnego, który miał ewolucyjnie zlikwidować rozdźwięk między ludźmi a ich (nowymi) miastami:

Trzecie pokolenie dawnych przybyszów na te ziemie związało się już bardzo mocno z nowym środowiskiem, które stało się dla niego czymś naturalnym i oczywistym. Tu bowiem są korzenie młodego pokolenia, które nie odczuwa już silnych związków emocjonalnych z dawnym miejscem urodzenia i zamieszkania ich dziadków i rodziców. Młode pokolenie dawnych Ziem Zachodnich i Północnych jest już stąd, bo tu się urodziło, wychowało i tutaj pracuje i żyje (Jacher, 2011, s. 77).

Jednak współcześnie prowadzone badania dowodzą, że ludzie zamieszkujący Ziemie Zachodnie i Północne tworzą społeczności postmigracyjne, pozbawione tożsamości regionalnej i własnej przestrzeni symbolicznej (zob. Durka, 2011; Sakson, 2011; Leoński, 2014), w których więzi społeczne ograniczają się do bezpiecznych ścian własnego domu/mieszkania - ścisłego kręgu rodzinnego i przyjacielskiego (zob. Kubicki, 2010; Smolarkiewicz, 2010). Nadal pozostaje otwarte pytanie, czy tworzona przez kolejne pokolenia ojczyzna prywatna, „krajobraz ojczysty” (Traba, 2006, s. 165) opiera się w jakiś sposób na zastanej kulturze materialnej. O tej nieoczywistej relacji kolejnego pokolenia mieszkańców z przestrzenią Ziem Zachodnich i Północnych pisze Robert Traba: „Co zrobić z poczuciem «bycia u siebie» trzeciej generacji ludzi urodzonych na ziemiach zachodnich i północnych, którzy konfrontują się z niepolskim krajobrazem Gdańska, Olsztyna, Wrocławia? Sprowadzić to wszystko do obrazu mazowiecko-warszawskiego?" (2006, s. 17).

Postawione wyżej pytania stanowią kontekst i punkt wyjścia dla moich rozważań nad jednym z ważniejszych ośrodków miejskich Ziem Zachodnich i Północnych - Wrocławiem. Jednak zagadnienia, które będę omawiała - konsekwencje zerwania więzi między człowiekiem a jego miejscem życia, relację między jednostką a (obcą?) architekturą, konstruowaną lokalnie pamięcią społeczną wyznaczającą ramy „miasta osobistego” (Majer, 2015) - można odnieść do każdego z miast tego obszaru.

Warto w tym miejscu postawić pytanie, czy zasadne jest zajmowanie się na początku XXI wieku społecznym konstruowaniem szeroko rozumianego dziedzictwa materialnego Breslau. Miasta, które zamieniono w 1945 roku w twierdzę, zostało zniszczone w ponad 70\% (Kosiński, 1967) i które później na kilkadziesiąt lat stało się miastem socjalistycznym ze wszystkimi tego konsekwencjami. Wreszcie miasta, którego podziurawioną podczas drugiej wojny światowej tkankę obecnie uzupełniają szklane biurowce i apartamentowce z piaskowca.

Istnieje kilka powodów sprawiających, że przyglądanie się społecznemu funkcjonowaniu owych niemieckich pozostałości w krajobrazie kulturowym Wrocławia jest słuszne i potrzebne.

Po pierwsze, badania socjologiczne i psychologiczne wskazują, że mieszkańcy najczęściej utożsamiają się z dwoma punktami na mapie miasta - własnym miejscem zamieszkania oraz jego kulturowym i administracyjnym centrum - starym miastem i śródmieściem (zob. np. Kajdanek, 2007; Lewicka, 2012). W centrum „miasto zyskuje swoje oblicze, daje się «zapamiętać», to ono sprawia, że miasto jest tym właśnie jedynym miastem odróżnialnym od innych" (Sławek, 1997, s. 18). W przypadku między innymi Wrocławia tak pojmowane centrum miasta definiuje zabudowa niemiecka. Przestrzeń ta spełnia również kryteria 
pozytywnie waloryzowanej idei miasta (którą tak doskonale naśladują centra handlowe) rdzeń miasta tworzą zbudowane w XIX i na początku XX wieku, a teraz systematycznie odnawiane ulice z domami towarowymi, zdobnymi kamienicami, a nie oderwane od miasta modernistyczne i socjalistyczne blokowiska (zob. Jałowiecki, 1989; Kajdanek, 2007; Łukasiuk, 2011).

Po drugie, wiele ważnych elementów zabudowy i infrastruktury przestrzeni publicznej, niezauważalnie wyznaczających codzienność życia człowieka i jego percepcję otoczenia - szkoły, urzędy, kościoły, szpitale, cmentarze, parki, domy towarowe (niezwykle istotne w socjalizmie), muzea; elementy sieciowe (ulice, drogi, kolej) oraz obiekty infrastrukturalne (dworce, mosty, stacje pomp, zajezdnie tramwajowe) - jest niemieckich, różniących się architektonicznie od ich odpowiedników w miastach Polski centralnej (zob. Thum, 2005).

\section{Wrocław - miasto o amputowanej pamięci ${ }^{3}$ czy „miasto spotkań” ${ }^{4}$}

Na polską tożsamość Wrocławia wpłynęło „pęknięcie między miejscem a społeczeństwem” (Margiela-Korczewska, 2011) spowodowane wydarzeniami 1945 roku i ich następstwami. Wymuszona polityką międzynarodową śmierć Breslau i narodziny na jego ruinach Wrocławia były (i prawdopodobnie nadal są) obciążeniem dla tworzenia relacji z miastem przez wrocławian: „we Wrocławiu nie było historii, poza piastowską gdzieś tam w mroku dziejów. Przeszłość nie istniała (...). Ta historyczna amnezja sprawiła, że zawsze czułam się we Wrocławiu obco. To miasto wydawało mi się uboższe, niepełne, nie moje" (Tuszyńska, 2003, s. 20).

Świadomość historyczna miasta zaczęła się budzić po przełomie 1989 roku. Podpisanie 14 listopada 1990 roku z Republiką Federalną Niemiec traktatu granicznego o nienaruszalności granicy na Odrze i Nysie Łużyckiej rozpoczęło proces wyciszania dotychczasowego poczucia tymczasowości i „niezadomowienia, które wiele lat po wojnie można było wyczytać z widoku wrocławskich ulic" (Dzikowska, 2006, s. 173). Zaczął się również zmieniać dyskurs publiczny, w którym w ostatniej dekadzie XX wieku rozpoczyna się proces przywracania pamięci o kilkuset latach istnienia miasta (zob. np. Mazur, 1997; Thum, 2005). Nowa tożsamość Wrocławia, konsekwentnie promowana przez jego władze od lat 90. XX wieku, opiera się na hasłach europejskości, wielokulturowości i otwartości. Ową wielokulturowość należy pojmować właściwie jako „wielohistoryczność” (Dolińska, Makaro, 2015, s. 88): „Warto zauważyć, że postulowana wielokulturowość Wrocławia ma przede wszystkim charakter historyczny, mówi bowiem o następujących po sobie okresach, w czasie których miasto było we władaniu różnych żywiołów etnicznych i narodowych" (Margiela-Korczewska, 2011, s. 188). Badania socjologiczne pokazują, że choć wrocławianie skwapliwie przyjęli narrację o wielokulturowości miasta, nie włączyli do osobistych narracji o mieście owych europejskich czy konkretnie czeskich, austriackich, niemieckich, żydowskich wątków (zob. np. Dolińska, Makaro, 2015). Najważniejszą wykładnią postrzegania miasta jest polska kultura narodowa i perspektywa drugiej wojny światowej (zob. Lewicka, 2006; Czajkowski, Pabjan, 2013). Co więcej, część badaczy podkreśla, że relacje z miastem kolejnych pokoleń mieszkańców są nadal nieułożone. Pojawiają się sformułowania, że „proces przejmowania miasta przez polskich wrocławian trwa już przez trzy pokolenia i jeszcze się

\footnotetext{
${ }^{3}$ Jest to sformułowanie autorstwa Andrzeja Zawady: „Wrocław jest miastem, któremu amputowano pamięć. Przyzwyczajałem się do niego z trudem, bo na każdym kroku przeszkadzało mi i dokuczało to jego wojenne inwalidztwo. Nie sposób iść ulicami miasta i nie myśleć o tym" (2015, s. 22).

${ }^{4}$ Tak brzmi oficjalne hasło promocyjne miasta, przyjęte uchwałą Rady Miejskiej w 1998 r.
} 
nie zakończył” (Dzikowska, 2006, s. 167) czy że „nastąpiło zerwanie społecznych struktur długiego trwania, wskutek tego kolejne, trzecie już żyjące na tych terenach pokolenie jest uczestnikiem sporu o pamięć" (Margiela-Korczewska, 2011, s. 176). Bez wątpienia zaproponowaną przez władze ideę wielokulturowego Wrocławia można odczytywać w tym kontekście jako sposób na uniknięcie konfrontacji z wciąż niejednoznacznymi i emocjonalnie trudnymi pozostałościami po Breslau. Jak podkreśla Andrzej Zawada: „Swoisty mit wielokulturowości części Ziem Zachodnich, np. Wrocławia czy Gdańska, pełni funkcję czynnika osłabiającego, czy «zmiękczającego» poniemieckość widoczną na co dzień zwłaszcza w architekturze i cywilizacyjnym ukształtowaniu krajobrazu" (2015, s. 93; zob. Mazur, 1997).

Drugą tożsamościową strategią miasta po 1989 roku, mniej widoczną w dyskursie publicznym i wymagającą szerszego opracowania naukowego, jest wizerunek Wrocławia jako spadkobiercy mieszczańskich tradycji Breslau (zob. Thum, 2005; Keck-Szajbel, 2011). O wartościach mieszczańskich jako pozanarodowej wykładni tożsamości Wrocławia wspomina Paweł Kubicki, który przytacza ciekawą, choć incydentalną i przedstawioną bez kontekstu metodologicznego wypowiedź jednego ze swoich respondentów:

Wrocław jest mieszczański, przecież raptem 70 lat temu byliśmy [wyróżnienia - P.K.] jedną ze stolic Rzeszy. Jeśli popatrzymy na przedwojenne fotografie, to Kraków wygląda na nich jak małe prowincjonalne miasteczko, drewniane budynki, błoto na ulicach (...). Natomiast Wrocław był wtedy prawdziwym miastem; wspaniałe budynki, szerokie ulice, świetnie ubrani ludzie (...). Kiedy w 1913 roku my budowaliśmy Halę Stulecia - symbol modernizmu, w tym samym czasie w Poznaniu budowano pseudogotycki zameczek typowy symbol zacofania (2010, s. 22).

\section{Wrocław - „miasto odzyskane”}

O utrzymującej się nieoczywistości relacji między wrocławianami a ich miastem świadczy konieczność tworzenia kolejnych mitów fundacyjnych, zastępujących peerelowskie sformułowania o piastowskości ziem i „polskich pionierach na «Dzikim Zachodzie»” (Dzikowska, 2006, s. 172). Wyróżniającym się obecnie w literaturze przedmiotu mitem początku miasta mającym integrować społeczność Wrocławia jest Wielka Powódź z 1997 roku, kiedy „mieszkańcy po raz pierwszy w historii [powojennej - P.K.] poczuli się zintegrowaną społecznością, już nie tylko zatomizowanymi jednostkami zamieszkującymi przestrzeń miasta, ale przede wszystkim jego obywatelami” (Kubicki, 2010, s. 21). Obrona przed rozlewającą się po mieście wodą zarówno najważniejszych dóbr kultury Wrocławia (Ostrowa Tumskiego, zbiorów Biblioteki Uniwersyteckiej czy Rynku), jak i codziennych przestrzeni życia miała scalić wrocławską społeczność, obudzić w niej pozytywne emocje wobec „odzyskanego" miasta (Sitek, 1997; Margiela-Korczewska, 2011). Trudno powiedzieć, na ile mit ten jest zinternalizowany przez wrocławian (i w jaki sposób przez różne społeczności - zob. Kowalewski, 2011) - brakuje gruntownych badań na ten temat. Jednak z pewnością powódź z 1997 roku jest na poziomie emocjonalnym momentem przełomowym w nawiązaniu relacji z przeszłością miasta, z Breslau - kataklizm sprawił, że „powrót do niepolskiej tradycji miasta stracił, tak częsty jeszcze, wymiar polsko-niemieckiej konkurencji o pamięć" (Traba, 2006, s. 55). 


\section{Wrocław. Pamiętam, że...}

Próbą dotarcia do istoty więzi wrocławian z miastem (i ze sobą nawzajem) był projekt „Wrocław. Pamiętam, że...” (Bierut, Pęcherz, 2015), przygotowany z okazji pełnienia przez Wrocław funkcji Europejskiej Stolicą Kultury w 2016 roku. Pomysł ten nie jest projektem naukowym i pod wieloma względami nie spełnia metodologicznych wymogów prac badawczych $^{5}$. Patrząc z tej perspektywy, można stwierdzić, że nie jest to „zapis zbiorowej pamięci mieszkańców Wrocławia" (Pęcherz, 2015, s. 7) ${ }^{6}$, jak chcieliby tego pomysłodawcy. Zastrzeżenia wobec projektu może budzić fakt, że redaktorzy wybierali i redagowali wypowiedzi umieszczone w książce - nie wiadomo, jak bardzo ingerowali w treść i dobór przedstawionych wspomnień. Nieznane są podstawowe informacje o osobach, które wzięły udział w tym przedsięwzięciu, takie jak wiek, wykształcenie, czas zamieszkiwania we Wrocławiu, miejsce pochodzenia przodków (co jest ważne chociażby dla przekazu międzypokoleniowego). Pewne informacje można w wielu przypadkach odtworzyć z samych wypowiedzi, na przykład wiek i wykształcenie - bardzo często w analizowanym materiale wspominany jest czas dzieciństwa i liceum/studiów. Na tej podstawie można również stwierdzić, że w omawianym projekcie nadreprezentowane są osoby o wyższym wykształceniu. Można również określić, że około dwie trzecie wypowiadających się osób to mieszkańcy Wrocławia od urodzenia lub od bardzo wczesnego dzieciństwa?. Wypowiedzi te wyraźnie układają się w głosy dwóch pokoleń wrocławian - drugiego (urodzeni w latach 40. i 50.) oraz trzeciego pokolenia mieszkańców (urodzeni w latach 70. i 80.) . $^{8}$

Pomimo powyżej wskazanych zastrzeżeń przedsięwzięcie „Wrocław. Pamiętam, że...” jest z wielu względów wyjątkowe. Choć tytuł projektu narzuca kontekst indywidualnych wspomnień (i tak podchodzą doń jego uczestnicy), jednak pamięciowy obraz miasta, jaki z nich powstaje, jest społeczny - społecznie wynegocjowany i ujednolicony - i jako taki „może stanowić podstawę wytwarzania wspólnej tożsamości czy, mówiąc ściślej, wrażenia o wspólnocie doświadczanej przestrzeni” (Kowalewski, 2011, s. 344).

Lektura tych krótkich, najczęściej jedno-, dwuzdaniowych wypowiedzi obnaża również trudności, z jakimi musi zmierzyć się badacz chcący uchwycić delikatne, często pozarefleksyjne relacje jednostek z przestrzenią codziennego życia. Przykładowo Katarzyna Kajdanek, badając społeczne konstruowanie i waloryzowanie centrum Wrocławia, zauważyła:

\footnotetext{
${ }^{5}$ Pomysłodawcy w taki sposób przedstawiali swój projekt: „Każdy, kto będzie chciał wziąć udział w wydarzeniu i wspomnieć Wrocław, będzie mógł przesłać propozycję swoich trzech zdań poprzez formularz zgłoszeniowy, który znajduje się na www.wroclawpamietamze.pl, przynieść osobiście lub przesłać pocztą tradycyjną (...). Redaktorzy książki wybiorą najciekawsze frazy z nadesłanych propozycji, ułożą je w całość i zredagują stylistycznie, a następnie przygotowany materiał zaistnieje w formie książki. Dzięki temu powstanie zbiorowy pamiętnik mieszkańców i gości Wrocławia, składający się z kilkuset - lub nawet kilku tysięcy - zdań «Pamiętam, że...». Pamiętnik ten będzie ukazywać historię miasta, jego mieszkańców - i bywalców - w zupełnym rozproszeniu i fragmentaryczności”, zob. Biuro ESK 2016 (2016).

${ }^{6}$ W pracy tej rozróżniam pojęcia pamięci zbiorowej i pamięci społecznej. Pamięć zbiorową definiuję jako pamięć określającą tożsamość zbiorową - widoczną w dominującym dyskursie publicznym i jego przekazach. Pamięć społeczną definiuję jako wynegocjowaną, uzgodnioną - intersubiektywną - pamięć jednostek, zob. Szacka (2006).

${ }^{7}$ Jeśli na podstawie wspomnień danej osoby można określić, z którego pokolenia pochodzi, podaję tę informację za pomocą cyfry rzymskiej w nawiasie po numerze nadanym wspominającemu przez redaktorów książki.

${ }^{8}$ Trzecią odrębną grupą osób, która odpowiedziała na apel organizatorów projektu „Wrocław. Pamiętam, że...” są osoby młodsze od wymienionych - obecni i byli studenci wrocławskich uczelni. Ich wspomnienia są inne - dotyczą głównie konsumpcji - i to zarówno w rozumieniu dosłownym, jak i przenośnym - barwnego życia towarzyskiego. Można je opisowo podsumować za pomocą jednej z wypowiedzi: „Pamiętam ostatnie edycje turniejów poetyckich im. Rafała Wojaczka w Czarnym Salonie. Pamiętam jeden rower, piec kaflowy i trzy akademiki. Jedną knajpę, wiele chwil i cztery kilogramy ziemniaków, z których zrobiłem frytki i zjadłem na jeden raz" (226).
} 
(...) brak natomiast samodzielności w poszukiwaniu wymiarów identyfikacji, brak niezwykłych, jednostkowo wyszukanych i doświadczanych miejsc magicznych, które przecież dużo mocniej przywiązują do miasta. Niestety, świadome poszukiwanie miejsc magicznych w mieście nie jest mocną stroną wrocławian, najwyraźniej nietęskniących za przydaniem miastu charakteru prywatnego czy też intymnego (2007, s. 120).

Natomiast wśród obrazów Wrocławia nadesłanych do analizowanego projektu można znaleźć wiele podkreślających „magiczność” relacji z miastem, przykładowo:

Pamiętam conocne spacery z Hali Ludowej na Borek, edycje Jazzu nad Odrą w latach siedemdziesiątych trwały tydzień, a tramwaj nocny był jak jednorożec. Synkopy, trampki i marzenia o bułce (41, II).

Pamiętam, że ulicą Świdnicką i Świerczewskiego [dziś Piłsudskiego] maszerowały: pelikan, słoń, krokodyl. Na dzień dobry witał neon „Dobry Wieczór”, a przechodniów rozśmieszał „Uśmiech za Uśmiech” (135, III).

Niewątpliwie treści tych spontanicznych (w znaczeniu - niewywołanych badawczą ingerencją) wspomnień zaskakują czytelnika obznajomionego z literaturą przedmiotu. Przykładowo w analizowanym zbiorze „miejscami znaczącymi”, wedle ujęcia Aleksandra Wallisa (1979), czyli takimi, w których doświadczenia jednostek skupiają się i zagęszczają, są wrocławskie tramwaje i dziś już nieistniejące kina studyjne. Obraz wrocławskiego Rynku zdominowany jest przez wspomnienia sprzed kilku dekad o ruchu kołowym i jeżdżących tu tramwajach, przy jednoczesnej nieobecności odwołań do Rynku jako „chluby” czy „wizytówki Wrocławia”. Te wypowiedzi, budujące istotny dyskursywnie - bo spójny i konsekwentny - obraz miasta, wymagają dalszego namysłu badawczego. Ramy artykułu uniemożliwiają pełniejsze zaprezentowanie tych danych, dlatego na następnych stronach zostanie przedstawiona ta ich część, która najbardziej koresponduje z poruszanymi w artykule zagadnieniami - odwołaniami do przedwojennej przeszłości miasta. Takich wspomnień jest ogółem kilkanaście na ponad 640 zebranych wypowiedzi. Ta niewielka ich ilość, mimo wspomnianego „uwolnienia” dyskursu publicznego w tworzeniu narracji o przeszłości miasta, może być konsekwencją wielu dekad przemilczeń o przedwojennej historii miasta i jego powojennych pozostałościach.

Sama nazwa przedwojennego miasta - Breslau - przywołana jest w całej publikacji tylko raz i to w kontekście na pierwszy rzut oka niezwiązanym z przedwojenną przeszłością: „Pamiętam, kiedy zacząłem o Wrocławiu myśleć inaczej. W 1997. Na stacji Opole Zachód spotkałem ludzi, którzy uciekali przed wielką wodą do Breslau. Wierzyli, że tam im nic nie grozi. Tobołki i ludzie, noc" (70, III).

Niewątpliwie jednak wspomnienie o ucieczce i sformułowanie „tobołki i ludzie, noc” może nawiązywać do utrwalonego medialnie obrazu uchodźców przybywających do lub uciekających z Wrocławia w 1945 roku i później. Nieobecność wśród zebranych wspomnień przedwojennej nazwy miasta może również świadczyć o skuteczności polityki władz w okresie PRL-u, kiedy „słowo Breslau wypowiadane było ściszonym głosem, jak przekleństwo, z dużą dozą emocji, bo trochę zakazane i niebezpieczne, albo wstydliwe" (Tuszyńska, 2003, s. 22).

Przedwojenni mieszkańcy Wrocławia - Niemcy - są bohaterami czterech wspomnień. Trzy z nich to reminiscencje z dzieciństwa drugiego pokolenia wrocławian, czyli już z okresu powojennego. Dotyczą one sytuacji bezpośredniego kontaktu z Innymi: 
Pamiętam z dzieciństwa mężczyznę bez nogi, w niemieckim szynelu, uśmiechnął się i podawał rękę dzieciom, mówiąc: „Majne dobry, dobry” (7, II).

Pamiętam, że Gertruda, córka właścicieli kamienicy, przychodziła regularnie po czynsz, a jej matka, Klara, co jakiś czas odwiedzała nas, aby trochę pogawędzić w swoim języku ojczystym (180, II).

Pamiętam, że przy ulicy Górnickiego na zwałach gruzów 1 października 1946 roku stare Niemki paliły świeczki. Po latach tam zamieszkałam. (...) (64, I).

Jedno wspomnienie jest wyjątkowe na tle całego zebranego materiału - wykracza ono poza doświadczenia własnego życia jednostki, sięga w przeszłość głębiej niż graniczny, wyznaczający „polskość” miasta rok 1945, wskazuje z imienia i nazwiska (z encyklopedyczną znajomością szczegółów biograficznych) obywatela Breslau. Paradoksalnie, jest to wyjątkowa dla całej publikacji wypowiedź również dlatego, że nawiązuje do współcześnie propagowanej w dyskursie publicznym Wrocławia wizji miasta europejskiego, dumnego ze swego kulturowego dziedzictwa i jego twórców: „Kto pamięta, że przy ulicy Piastowskiej 25 mieszkał w latach 1907-1921 Franz J. Spribille (1841-1921), absolwent tutejszego uniwersytetu, emerytowany profesor gimnazjalny, europejskiej sławy botanik?" (230, II).

Wrocławianie kilkakrotnie używają w swych wspomnieniach przymiotnika poniemiecki. Jest to określenie ważne, nadal będące podstawą „wspólnych sensów” kolejnych pokoleń mieszkańców Ziem Zachodnich i Północnych (i jako takie wymagające bliższej analizy). Jego treść zmienia się prawdopodobnie wraz z upływem czasu, jednak nadal jest ono sposobem zdystansowania się, łagodzenia opisu i rozumienia tego, co zostało, co przetrwało z kultury przedwojennego miasta - czyli tego, co niemieckie. Te wspomnienia to przede wszystkim zapis obrazów z dzieciństwa:

Pamiętam poniemieckie śliwy rosnące na moim podwórku przy Ulanowskiego, a także jabłonki i mirabelki, parkany porastała winorośl, i my te wszystkie owoce jedliśmy prosto z drzewa, bez mycia i bez pytania (174, III).

Pamiętam kawałki cegieł z poniemieckich domów. Nazywaliśmy je „kredą” i rysowaliśmy nimi na podwórku (8).

Pamiętam, że (...) po wojnie pod mostem Warszawskim w kanale Odry stał zatopiony poniemiecki, uszkodzony czołg, do którego wpływaliśmy i wyciągaliśmy stamtąd gramofonowe płyty, które służyły nam wyłącznie do zabawy (21, II).

Przymiotnik niemiecki przywołany jest w analizowanym zbiorze dwukrotnie. Na podstawie analizowanego materiału nie można stwierdzić, czy określenie to jest inaczej osadzone znaczeniowo niż wcześniej przedstawiony termin poniemiecki. Być może użycie tego pojęcia podkreśla dystans wobec „dziedzictwa”, które nie może zostać przyswojone, zaakceptowane, dołączone do społecznie konstruowanego obrazu Wrocławia: faszystowskie monety, szczątki Niemców. Refleksja ta wymaga jednak dalszych badań i analiz na szerszym materiale badawczym:

Pamiętam dwie niemieckie monety ze swastyką znalezione w latach siedemdziesiątych w piaskownicy przy ulicy Iwana Pawłowa (25, III). 
Pamiętam, że w czasach gomułkowskich na cmentarzu przy ulicy Bujwida hieny nocą rozkopywały niemieckie groby $(230$, II).

Przedwojenna przestrzeń miasta przywołana jest przede wszystkich za pomocą obrazów jego powojennych szczątków. W zebranych wspomnieniach dziedzictwa niemieckiego nie tworzą zachowane nobliwe zabytki architektury czy nawet przemierzane codziennie ulice, lecz ślady bezimiennej śmierci. Wspomnienia mieszkańców konstruowane są z perspektywy dzieci, którymi byli - odkrywającymi to, co zakryte, a przy tym obce, być może zakazane:

Pamiętam mnóstwo ludzkich kości wydobywanych przez koparki na Legnickiej. Nasz blok wybudowano na cmentarzu. Podobno pochowano w nim wielu zasłużonych przedwojennych wrocławian (28).

Pamiętam wrażenie po wielkich ulewach, wzdłuż Legnickiej odsłaniały się fragmenty piwnic, podziemie byłego, nieistniejącego miasta (30).

Pamiętam, że (...) największą atrakcją po przedszkolu było kopanie w parku Zachodnim i wygrzebywanie ciekawostek z byłego cmentarza (210, III).

Ciekawym wyjątkiem są obrazy Breslau nadesłane przez jednego z uczestników projektu. Pojawia się w nich nie tylko niezwykła znajomość architektury i topografii przedwojennego miasta, niemieckich nazw jego ulic, lecz także żal spowodowany ich stratą. Ważne jest zastosowanie dystansującego tożsamościowo po waszemu:

Pamiętam o tym, że na Köhlenstrasse (po waszemu Dubois) na początku, od strony placu Maxa Borna, stały kamienice. Miały taki neorenesansowy niderlandzki ornament okuciowy. Chciałbym, żeby stały tam nadal (51).

Pamiętam także kostkę brukową na Friedrich-Wilhelm-Strasse (po waszemu Legnicka). Chciałbym, żeby była tam nadal. Nie pamiętam, żeby stały tam kamienice, ale chciałbym, żeby stały tam nadal (51).

\section{Podsumowanie}

Celem artykułu było przedstawienie tych obszarów społecznie wynegocjowanej relacji między jednostką a miastem, które wciąż czekają na badania socjologiczne. Niewątpliwie jest to obszar badań niezwykle trudny. Zwykle codzienne bytowanie w mieście, styczność z zamkniętymi w materii miasta depozytami pamięci jest dla jego mieszkańców często bezrefleksyjne - trudne do wyartykułowania: „Z miastem wiąże człowieka praca, dom, krajobraz, budynki, zabytki, ulice, atmosfera często niepowtarzalna i ludzie. Człowiek w różnym stopniu odczuwa swoją więź z miastem; jedni uświadamiają ją sobie w pełni, wiedzą na czym polega, inni zaledwie przeczuwają jej istnienie" (Goćkowski, Jałowiecki, 1970, s. 37). W tym ujęciu miasto jest oswojonym, konstruowanym na poziomie codzienności fragmentem świata - domami, ulicami, swojskimi krajobrazami, za którymi tęskni, które „nosi w sercu”, które się wskazuje jako „element siebie”. Wszystkie te detale środowiska istnienia jednostki są kluczowe dla jej życia społecznego: kształtują jej postrzeganie świata, ukierunkowują jej myślenie, nadają treść przyjmowanym tożsamościom. Badania nad tak rozumianymi miejscami pamięci - również w kontekście Wrocławia - prowadzą kulturoznawcy (Saryusz-Wolska, 2011; Miściorak, 2015), geografowie społeczni (Kołodziejczyk, Chylińska, 
Zaręba, 2014) czy literaturoznawcy (Taranek-Wolańska, 2013; Rybicka, 2014). Jednak to perspektywa socjologiczna i prowadzone w jej ramach jakościowe badania empiryczne dają możliwość bezpośredniego dotarcia do „światów społecznych” jednostek i ich społecznie uzgodnionych i doświadczanych miejsc pamięci.

Pamięć społeczna, tworzona w codziennych, prozaicznych działaniach, dalece wykracza poza „oficjalne” sposoby upamiętnień - tablice i pomniki - które dominują w polskim obszarze badaniach nad kolektywnymi konstruktami pamięciowymi (zob. np. Kończal, Wawrzyniak, 2011). Życie w mieście, rozumiane jako „stały, codzienny, trwający wiele lat kontakt z tymi samymi dziełami architektury, kompozycją przestrzeni, detalami architektonicznymi czy miejskim umeblowaniem" (Jałowiecki, 1989, s. 33), socjalizuje człowieka, jego postrzeganie świata, wartościowanie (zob. Łukasiuk, 2011). Dlatego warto postawić pytanie o to, co się dzieje, gdy przestrzeń identyfikacji jednostki, a co za tym idzie - jej pamięć społeczna, wyłamuje się z ram dyskursu dominującego, nadal wyznaczanego perspektywą makrospołeczną - przede wszystkim narodową.

\section{LITERATURA}

Bartkowski, J. (2003). Tradycja i polityka. Wpływ tradycji kulturowych polskich regionów na współczesne zachowania społeczne i polityczne. Warszawa: Wydawnictwo Akademickie Żak.

Bereś, S. (S. Nowicki) (1993). Amarcord Wrocławski. Rozmowa z Sebastianem Lamarck. Odra, 5, 50-53.

Bierut, J., Pęcherz, K. (red.) (2015). Wrocław. Pamiętam, że... Wrocław: Fundacja na rzecz Kultury i Edukacji im. Tymoteusza Karpowicza.

Biuro ESK 2016 (2016). Wrocław. Pamiętam, że... - i ty możesz napisać książkę! Pobrano z: http:// www.wroclaw.pl/wroclaw-pamietam-ze-i-ty-mozesz-napisac-ksiazke (dostęp 13.12.2016).

Czajkowski, P., Pabjan, B. (2013). Pamięć zbiorowa mieszkańców Wrocławia a stosunek do niemieckiego dziedzictwa miasta. W: J. Juchnowski, R. Wiszniowski (red.), Współczesna teoria i praktyka badań społecznych i humanistycznych (t. 1, s. 739-761). Toruń: Wydawnictwo Adam Marszałek.

Dolińska, K., Makaro, J. (2015). Wielokulturowość Wrocławia i stosunek jego mieszkańców do Innych. W: M. Błaszczyk, J. Pluta (red.), Uczestnicy, konsumenci, mieszkańcy. Wrocławianie i ich miasto w oglądzie socjologicznym (s. 70-101). Warszawa: Wydawnictwo Naukowe Scholar.

Durka, W. (2011). Orientacje teoretyczne w badaniach socjologicznych Ziem Zachodnich i Północnych Polski (w latach 1945-1990). W: A. Michalak, A. Sakson, Ż. Stasieniuk (red.), Polskie Ziemie Zachodnie. Studia socjologiczne (s. 53-66). Poznań: Wydawnictwo Instytutu Zachodniego.

Dzikowska, E.K. (2006). Tożsamość Wrocławia(n), czyli o możliwościach życia ponad podziałami. W: P. Żuk, J. Pluta (red.), My Wrocławianie. Społeczna przestrzeń miasta (s. 165-180). Wrocław: Wydawnictwo Dolnośląskie.

Goćkowski, J., Jałowiecki, B. (1970). Prace nadesłane na konkurs „Czym jest dla ciebie miasto Wrocław" jako materiał socjologiczny. W: B. Jałowiecki (red.), Związani z miastem... Opra- 
cowanie i fragmenty wypowiedzi (s. 11-71). Wrocław-Warszawa-Kraków: Zakład Narodowy im. Ossolińskich - Wydawnictwo.

Gurwitsch, A. (1989). Problemy świata przeżywanego. W: Z. Kranodębski (red.), Fenomenologia i socjologia. Zbiór tekstów (s. 151-185). Warszawa: Państwowe Wydawnictwo Naukowe.

Jacher, W. (2011). Problemy adaptacji społeczno-kulturowej ludności polskiej na Ziemiach Zachodnich i Północnych po 1945 roku. W: A. Michalak, A. Sakson, Ż. Stasieniuk (red.), Polskie Ziemie Zachodnie (s. 67-78). Poznań: Wydawnictwo Instytutu Zachodniego.

Jałowiecki, B. (1989). Przestrzeń znacząca. W: J. Wódz (red.), Przestrzeń znacząca. Studia socjologiczne (s. 14-39). Katowice: Śląski Instytut Naukowy.

Kajdanek, K. (2007). Centrum Wrocławia - przemiany funkcjonalno-przestrzenne i ich percepcja. W: I. Borowik, K. Sztalt (red.), Współczesna socjologia miasta. Wielość oglądów i kierunków badawczych (s. 105-120). Wrocław: Wydawnictwo Uniwersytetu Wrocławskiego.

Kaltenberg-Kwiatkowska, E. (2007). Socjologia przestrzeni w Polsce. Narodziny subdyscypliny. W: I. Borowik, K. Sztalt (red.), Współczesna socjologia miasta. Wielość oglądów i kierunków badawczych (s. 9-24). Wrocław: Wydawnictwo Uniwersytetu Wrocławskiego.

Keck-Szajbel, M. (2011). Cives Wratislavienses, czyli pamięć o Niemcu na Śląsku. W: D. Margiela-Korczewska, K. Ruchniewicz (red.), Błogosławiony kraj? Szkice o historii i pamięci Dolnego Śląska (s. 157-172). Wrocław: Oficyna Wydawnicza Atut.

Kołodziejczyk, K., Chylińska, D., Zaręba, A. (red.) (2014). Studia Krajobrazowe. T. 4: Krajobraz jako nośnik idei. Ujęcia teoretyczne i humanistyczne. Wrocław: Instytut Geografii i Rozwoju Regionalnego Uniwersytetu Wrocławskiego.

Kończal, K., Wawrzyniak, J. (2011). Polskie badania pamięcioznawcze: tradycje, koncepcje, (nie)ciągłości. Kultura i Społeczeństwo, 4, 11-64.

Kornecki, M. (1991). Krajobraz kulturowy, perspektywy badań i ochrony. Ochrona Zabytków, 1, 19-25.

Kosiński, L. (1967). Przeobrażenia demograficzne na Ziemiach Zachodnich. W: W. Markiewicz, P. Rybicki (red.), Przemiany społeczne na Ziemiach Zachodnich (s. 78-131). Poznań: Wydawnictwo Instytutu Zachodniego.

Kowalewski, M. (2011). „Tam, gdzie kiedyś był Komitet Wojewódzki”. Czy istnieje wspólna pamięć o mieście? Przegląd Socjologiczny, 60 (2-3), 343-364.

Kubicki, P. (2010). Nowi mieszczanie - nowa generacja. Wrocław - miasto odzyskane. W: J. Zając (red.), Pokolenie - kategoria historyczna czy współczesna? Obraz przemian pokoleniowych w sztuce i społeczeństwie XX i XXI wieku (s. 12-24). Kraków: Księgarnia Akademicka.

Leoński, J. (2014). Społeczeństwo Ziem Zachodnich - społeczeństwo bez historii. Konsekwencje dla współczesności i przyszłości. W: Z. Kurcz, Ż. Stasieniuk (red.), Od Polonii po Ziemie Zachodnie (s. 67-98). Szczecin: Oddział Szczeciński Polskiego Towarzystwa Socjologicznego.

Lewicka, M. (2006). Dwa miasta - dwa mikrokosmosy. Wrocław i Lwów w pamięci swoich mieszkańców. W: P. Żuk, J. Pluta (red.), My Wrocławianie. Społeczna przestrzeń miasta (99-134). Wrocław: Wydawnictwo Dolnośląskie.

Lewicka, M. (2012). Psychologia miejsca. Warszawa: Wydawnictwo Naukowe Scholar.

Łukasiuk, M. (2011). Socjologia architektury w badaniach krajobrazu kulturowego miasta. Przegląd Socjologiczny, 60 (2-3), 93-110.

Majer, A. (2015). Mikropolis. Socjologia miasta osobistego. Łódź: Wydawnictwo Uniwersytetu Łódzkiego. 
Margiela-Korczewska, D. (2011). „Poświęcić czas historii” - w poszukiwaniu wrocławskiego dziedzictwa. O polityce historycznej lat dziewięćdziesiątych we Wrocławiu. W: D. Margiela-Korczewska, K. Ruchniewicz (red.), Błogosławiony kraj? Szkice o historii i pamięci Dolnego Śląska (s. 137-156). Wrocław: Oficyna Wydawnicza Atut.

Mazur, Z. (1997). Wprowadzenie. W: Z. Mazur (red.), Wokół niemieckiego dziedzictwa kulturowego na Ziemiach Zachodnich i Północnych (s. I-XXVI). Poznań: Wydawnictwo Instytutu Zachodniego.

Miściorak, A. (2015). Krajobraz jako nieświadoma pamięć miasta. Przykład Wrocławia. Kultura Współczesna, 4, 124-141.

Nowakowski, S. (1967). Procesy adaptacji i integracji w środowisku wiejskim i miejskim Ziem Zachodnich. W: W. Markiewicz, P. Rybicki (red.), Przemiany społeczne na Ziemiach Zachodnich (s. 132-177). Poznań: Wydawnictwo Instytutu Zachodniego.

Pęcherz, K. (2015). Wstęp. W: J. Bierut, K. Pęcherz (red.), Wrocław. Pamiętam, że... (s. 7). Wrocław: Fundacja na rzecz Kultury i Edukacji im. Tymoteusza Karpowicza.

Rogowski, Ł. (2016). Wideozwiedzanie. Badania miasta w perspektywie paradygmatu mobilności. Kultura i Społeczeństwo, 2, 123-144.

Rossi, A. (1999). The Architecture of the City. Cambridge: MIT Press.

Rybicka, E. (2014). Geopolityka. Przestrzeń i miejsce we współczesnych teoriach i praktykach literackich. Kraków: Universitas.

Sakson, A. (2011). Przemiany tożsamości lokalnej i regionalnej mieszkańców Ziem Zachodnich i Północnych. W: A. Michalak, A. Sakson, Ż. Stasieniuk (red.), Polskie Ziemie Zachodnie (s. 79-100). Poznań: Wydawnictwo Instytutu Zachodniego.

Saryusz-Wolska, M. (2011). Spotkanie czasu z miejscem. Studia o pamięci i miastach. Warszawa: Wydawnictwa Uniwersytetu Warszawskiego.

Schütz, A. (1984). Potoczna i naukowa interpretacja ludzkiego działania. W: E. Mokrzycki (red.) Kryzys i schizma. Antyscjentystyczne tendencje w socjologii współczesnej (s. 137-192). Warszawa: Państwowy Instytut Wydawniczy.

Sitek, W. (1997). Wspólnota i zagrożenie. Wrocławianie wobec wielkiej powodzi. Wrocław: Wydawnictwo Uniwersytetu Wrocławskiego.

Sławek, T. (1997). Akro/nekro/polis: wyobrażenia miejskiej przestrzeni. W: A. Zeidler-Janiszewska (red.), Pisanie miasta - czytanie miasta (s. 14-34). Poznań: Wydawnictwo Fundacji Humaniora.

Smolarkiewicz, E. (2010). „Przerwana” tożsamość. Odtwarzanie i tworzenie tożsamości w społecznościach postmigracyjnych. Poznań: Wydawnictwo Naukowe UAM.

Szacka, B. (2006). Czas przeszły - pamięć - mit. Warszawa: Wydawnictwo Naukowe Scholar.

Taranek-Wolańska, O. (2013). Stacja Wałbrzych, czyli transgraniczność i doświadczanie miejsca. W: M. Ursel, O. Taranek-Wolańska (red.), Śląskie pogranicza kultur (t. 2, s. 145-158). Wrocław: Oficyna Wydawnicza Atut.

Thum, G. (2005). Obce miasto. Wrocław 1945 i potem. Wrocław: Via Nova.

Traba, R. (2006). Historia - przestrzeń dialogu. Warszawa: Wydawnictwo Instytutu Studiów Politycznych PAN.

Tuszyńska, A. (2003). Kiedy myślę Polska, myślę „Europa”. Rozmowa z Ewą Stachniak. Odra, 6, 20-22. 
Wallis, A. (1979). Gwar i informacja: o miejskim centrum. Warszawa: Państwowy Instytut Wydawniczy.

Zawada, A. (2015). Drugi Bresław. Wrocław: Oficyna Wydawnicza Atut.

I REMEMBER... OF SOCIAL CONSTRUCTION OF MEMORY OF THE CITY DWELLERS IN THE WESTERN AND NORTHERN TERRITORIES ON THE EXAMPLE OF WROCŁAW

SUMmARY The objective of this article is to present topics of social memory, which, on one hand, are based on the personal, everyday experience of an individual, and on the other hand, are incorporated into a socially negotiated framework of collective memory. The article is also a part of the discussion on sites of memory and their possible content - going beyond museums, monuments, commemorative plaques or cemeteries that maintain the collective memory - implemented in everyday life of an individual. The subject of the analyses is the social memory of the people living in Wrocław, their construction of social worlds based on a space which is culturally burdened with the "memory of the absent".

\section{KEYWORDS}

SOCIAL MEMORY, SITES OF MEMORY, DISCOURSE ANALYSIS, IDENTITY, THE WESTERN AND NORTHERN

TERRITORIES, WROCŁAW 